\title{
How to build functional thylakoid membranes: from plastid transcription to protein complex assembly
}

\author{
Dagmar Lyska $\cdot$ Karin Meierhoff $\cdot$ Peter Westhoff
}

Received: 20 July 2012 / Accepted: 10 August 2012 / Published online: 14 September 2012

(C) The Author(s) 2012. This article is published with open access at Springerlink.com

\begin{abstract}
Chloroplasts are the endosymbiotic descendants of cyanobacterium-like prokaryotes. Present genomes of plant and green algae chloroplasts (plastomes) contain $\sim 100$ genes mainly encoding for their transcription-/translationmachinery, subunits of the thylakoid membrane complexes (photosystems II and I, cytochrome $b_{6} f$, ATP synthase), and the large subunit of ribulose-1,5-bisphosphate carboxylase/ oxygenase. Nevertheless, proteomic studies have identified several thousand proteins in chloroplasts indicating that the majority of the plastid proteome is not encoded by the plastome. Indeed, plastid and host cell genomes have been massively rearranged in the course of their co-evolution, mainly through gene loss, horizontal gene transfer from the cyanobacterium/chloroplast to the nucleus of the host cell, and the emergence of new nuclear genes. Besides structural components of thylakoid membrane complexes and other (enzymatic) complexes, the nucleus provides essential factors that are involved in a variety of processes inside the chloroplast, like gene expression (transcription, RNA-maturation and translation), complex assembly, and protein import. Here, we provide an overview on regulatory factors that have been described and characterized in the past years, putting
\end{abstract}

A contribution to the special issue on Evolution and Biogenesis of Chloroplasts and Mitochondria.

D. Lyska $(\varangle) \cdot$ K. Meierhoff $\cdot$ P. Westhoff

Entwicklungs- und Molekularbiologie der Pflanzen,

Heinrich-Heine-Universität Düsseldorf, Universitätsstr. 1, 40225 Düsseldorf, Germany

e-mail: dalyska@lbl.gov

Present Address:

D. Lyska

Physical Biosciences Division, Lawrence Berkeley National Laboratory and Department of Plant and Microbial Biology,

University of California, Berkeley, CA 94720-3102, USA emphasis on mechanisms regulating the expression and assembly of the photosynthetic thylakoid membrane complexes.

Keywords Chloroplast · Complex assembly · Endosymbiosis · Gene expression · Photosynthesis · Thylakoid membrane

$\begin{array}{ll}\text { Abbreviations } \\ \text { CES } & \text { Control by epistasis of synthesis } \\ \text { HAT } & \text { Half-a-TPR } \\ \text { NEP } & \text { Nuclear-encoded RNA polymerase } \\ \text { PEP } & \text { Plastid-encoded RNA polymerase } \\ \text { PPR } & \text { Pentatricopeptide repeat } \\ \text { PSI } & \text { Photosystem I } \\ \text { PSII } & \text { Photosystem II } \\ \text { SD } & \text { Shine-Dalgarno } \\ \text { TPR } & \text { Tetratricopeptide repeat }\end{array}$

\section{Introduction}

Chloroplasts are the characteristic organelles of plants and algae. They are the sites of photosynthesis, converting light to chemical energy and atmospheric $\mathrm{CO}_{2}$ to carbohydrates, as well as other essential processes like lipid metabolism, biosynthesis of amino acids, purine and pyrimidine bases, chlorophyll, and other tetrapyrroles (Neuhaus and Emes 2000; Finkemeier and Leister 2010).

The light-dependent reactions of photosynthesis, where light energy is fixed and converted to ATP and NADPH, are performed by four large thylakoid membrane-associated protein complexes: photosystems II and I (PSII and PSI) interconnected by the cytochrome $b_{6} f$ complex, and ATP synthase. 
Linear electron transport through the thylakoid membrane begins with the excitation of a chlorophyll pair, P680, at PSII and transfer of electrons to plastoquinone. $\mathrm{P} 680^{+}$is de-excited by electrons generated from water oxidation via the manganese cluster at the oxygen-evolving complex (OEC) at the lumenal side of PSII. Electrons from plastoquinol are transferred to PSI via the cytochrome $b_{6} f$ complex and either plastocyanin or cytochrome $c_{6}$. Finally, PSI passes electrons to ferredoxin, which reduces $\mathrm{NADP}^{+}$to NADPH with the help of ferredoxin-NADPH oxidoreductase (FNR). Linear electron transport is coupled to the translocation of protons from the stroma to the lumen generating the proton motive force that drives ATP synthesis from ADP and inorganic phosphate by the ATP synthase (Nelson and Ben-Shem 2004). In addition, electrons generated on the reducing side of PSI can be re-injected into the plastoquinone pool, thus generating an additional proton motive force and boosting ATP synthesis, a process called cyclic electron transport (Munekage et al. 2004; Munekage and Shikanai 2005; Shikanai 2007).

Phylogenetic, structural, and biochemical analyses show that primary plastids developed $1.2-1.5$ billion years ago from a cyanobacterium-like ancestor engulfed by a mitochondrium-possessing eucaryote (Martin and Russell 2003). Comparison of present cyanobacterial genomes with plastid genomes (plastomes) points to massive loss of genetic information as a consequence of endosymbiotic events. Whereas cyanobacteria like Anabaena sp. PCC 7120 and Synechocystis sp. PCC3168 have 5,366 and 3,268 proteinencoding genes, respectively (Kaneko et al. 1996, 2001), plastomes encode for significantly less proteins [Arabidopsis thaliana: 87 (Sato et al. 1999), Chlamydomonas reinhardtii: 99 (Maul et al. 2002)]. However, the total number of plastid proteins is estimated to be between 2,000 and 3,600 (Leister 2003; Richly and Leister 2004) and thus overall correlates to the protein content of cyanobacteria. These numbers imply that the majority of the genes were transferred to the nucleus or lost in the course of co-evolution of the symbiont and its host cell. Genes that were retained in the plastid genome mainly encode for its transcription- and translation-machinery, as well as for subunits of the thylakoid membrane complexes and the large subunit of ribulose-1,5-bisphosphate carboxylase/oxygenase (Martin et al. 2002; Timmis et al. 2004).

The lateral transfer of major parts of the plastid ancestral genome to the nucleus and the emergence of novel nuclearencoded, plastid-localized proteins require coordination of nuclear and plastid gene expression. Retrograde (plastid-tonucleus) and anterograde (nucleus-to-plastid) signaling mechanisms evolved to permit communication between the two compartments (Woodson and Chory 2008). Plastids transmit their developmental or functional state by signals, which originate from (1) plastid gene expression, (2) pigment biosynthesis (e.g., tetrapyrroles), (3) reactive oxygen species, (4) redox states of the components of the photosynthetic electron transport, and (5) metabolite pool changes (Pogson et al. 2008; Kleine et al. 2009; Pfannschmidt 2010). On the other hand, the nucleus controls (1) all steps of plastid gene expression (transcription, RNA-processing, -editing, -stability, translation), (2) complex assembly, (3) protein import, and (4) enzyme activity in response to plastid, developmental and environmental signals (Fig. 1; Woodson and Chory 2008). In addition, it encodes structural components of the photosynthetic thylakoid membrane complexes and other complexes (Fig. 1; Herrmann et al. 1985; Wollman et al. 1999).

\section{Regulation of transcription}

In higher plants, transcription of plastid genes is performed by distinct RNA polymerases, one plastid-encoded RNA polymerase (PEP) and two nuclear-encoded RNA polymerases (NEP) named RPOTp and RPOTmp (Maliga 1998; Liere and Börner 2007). The nuclear-encoded polymerases are monomeric phage-type enzymes (Lerbs-Mache 1993; Courtois et al. 2007; Swiatecka-Hagenbruch et al. 2007), which have evolved only in seed plants and mosses by duplication of the gene encoding a mitochondrial phagetype enzyme (Hedtke et al. 1997, 2000). These polymerases could not be identified in green algae. Most NEP-dependent promoters exhibit a YRTA sequence motif similar to plant mitochondrial promoters (Kühn et al. 2005) and show no similarity to PEP-dependent promoters. NEP is thought to drive expression of housekeeping genes during early phases of plastid and plant development (Lerbs-Mache 1993; Mullet 1993; Hajdukiewicz et al. 1997). However, NEP is also present in mature chloroplasts, driving transcription of genes encoding ClpP (a proteolytic subunit of ATP-dependent protease), ribosomal proteins and ribosomal RNA (Bligny et al. 2000; Cahoon et al. 2004; Azevedo et al. 2006; Swiatecka-Hagenbruch et al. 2008).

The plastid-encoded RNA polymerase is a multimeric eubacterial-type enzyme, which recognizes "consensus" promoters having the conserved sequences TTGACA and TATAAT centered at 35 and $10 \mathrm{bp}$ upstream from a transcriptional initiation site, respectively (Harley and Reynolds 1987; Ishihama 1988; Lonetto et al. 1992). The PEP core enzyme consists of subunits $\alpha, \beta, \beta^{\prime}$ and $\beta^{\prime \prime}$, which are encoded by the genes rpoA, rpoB, rpoCl, and rpoC2 of the plastid genome, respectively (Shiina et al. 2005). PEP is regulated by nuclear-encoded sigma factors, which bind to the core enzyme to form the holoenzyme and initiate transcription. Most higher plant genomes encode six sigma factors (SIG1-6; except poplar, which has nine). In contrast, only one sigma factor gene has been identified in 


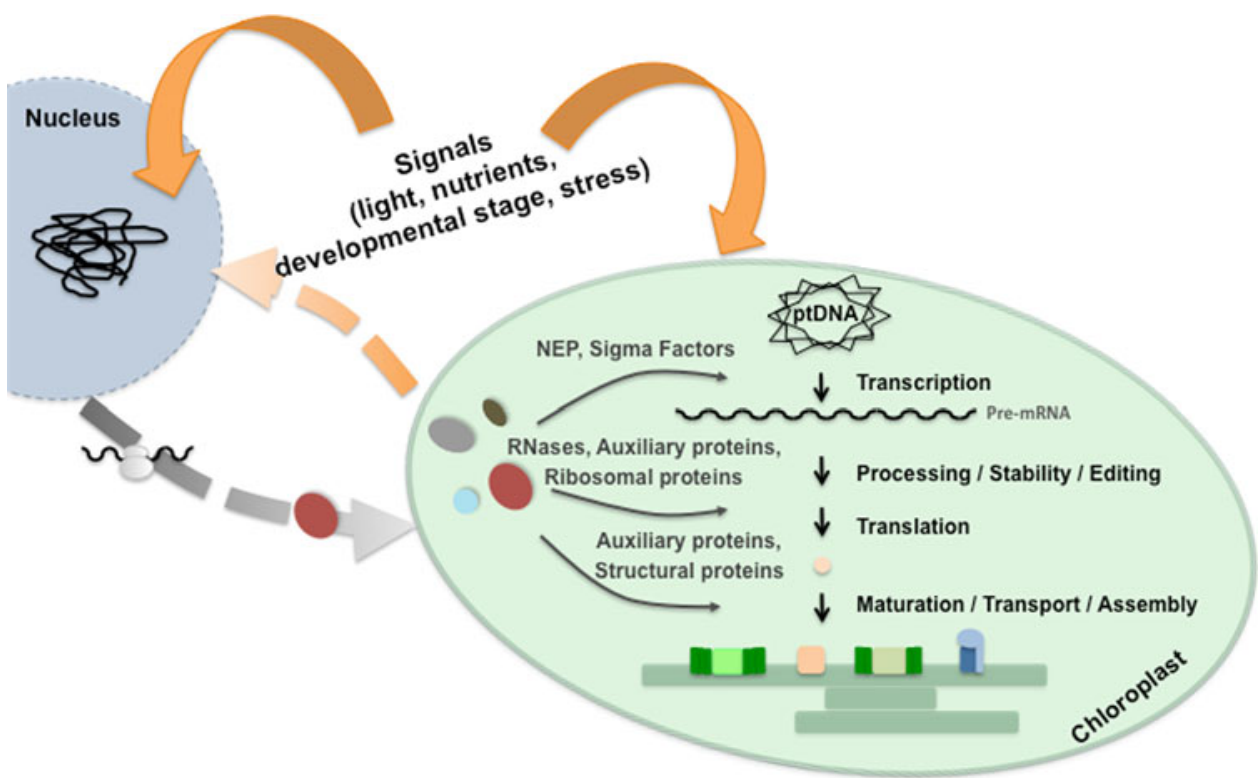

Fig. 1 Overview of regulation levels of plastid gene expression and thylakoid membrane complex formation. Exo and endogenous signals influence nuclear and plastid gene expression, which again intercommunicate by retrograde and anterograde signals. Anterograde signals, i.e., nuclear-encoded factors that are synthesized in the cytosol and post-translationally transported into the chloroplast, control plastid gene expression from transcription, via maturation of transcripts, to translation. Also, the maturation, transport, and assembly of the thylakoid membrane complexes underlie regulation by nuclear-encoded factors. ptDNA plastid DNA, $N E P$ nuclear-encoded RNA polymerase green algae, and it is not an ortholog to any plant gene (Carter et al. 2004; Lysenko 2007). Sigma factors are thought to have distinct functions in the regulation of plastid gene expression (Lysenko 2007; Lerbs-Mache 2011). Analyses of sigma factor mutants, mostly carried out in Arabidopsis, revealed that at least two sigma factors are essential for photoautotrophic growth (SIG2 and SIG6; Shirano et al. 2000; Ishizaki et al. 2005; Loschelder et al. 2006) and that each sigma factor is specific for one or several plastid genes (Lerbs-Mache 2011). Transcription of sigma factor genes SIG1 and SIG5 is induced by red and blue light, thus indicating a function under specific light conditions (Onda et al. 2008). Also, activity of sigma factors is believed to be modulated by redox reactions, phosphorylation, interaction with other proteins, and eventually proteolytic cleavage (Lerbs-Mache 2011). Several proteomic studies have identified additional putative components of the PEP complex of Arabidopsis, tobacco, and mustard (Suzuki et al. 2004; Pfalz et al. 2006; Schröter et al. 2010; Steiner et al. 2011). However, which of the identified factors truly associate with PEP complexes and their precise functions in transcription are still under discussion.

Originally, PEP-dependent transcription was assumed to play a role in later developmental stages of plants through transcription of photosynthesis-related genes (Mullet 1993). However, recent studies revealed that PEP is already active in seeds and is required for efficient germination (Demarsy et al. 2006). Also, both NEP and PEP were found to be active throughout the entirety of leaf development (Zoschke et al. 2007) and almost all plastid genes are transcribed from several independent promoters, allowing access to NEP as well as to PEP (Swiatecka-Hagenbruch et al. 2007). Together with the redundancy of some sigma factors and the lack of NEP and diversity of sigma factors in green algae, these results raise the question whether all of these factors are truly required for regulation of gene expression (Lerbs-Mache 2011). Maier et al. (2008) provide an alternative hypothesis, which proposes that the large number of regulatory nuclear-encoded factors has evolved in order to suppress point mutations occurring in plastid promoter regions, i.e., to assure constant plastid genome transcription by continually creating new promoter/polymerase pairs.

\section{Transcript maturation}

Transcript maturation plays a vital role in the regulation of plastid gene expression. A broad range of nuclear-encoded factors has been described as performing and assisting in processing, editing, and splicing of plastid transcripts (reviewed in Stern et al. 2010; Barkan 2011). Recently, a proteomic study of nucleoids isolated from proplastids and mature chloroplasts from maize leaves identified a large number of proteins with RNA-related functions (1) indicating that transcript maturation occurs co-transcriptionally and (2) providing a set of new, so far uncharacterized proteins putatively involved in transcript maturation (Majeran 
et al. 2012). Here, we give a short overview of regulation of plastid transcript maturation. A detailed review on transcript processing is provided elsewhere in this issue.

\section{Transcript processing}

In plastids, newly synthesized transcripts undergo several maturation steps prior to translation. Most genes are arranged in polycistronic gene clusters and transcribed from a single promoter (Herrmann et al. 1992; Sugiura 1992). As translation of monocistronic RNAs is often more effective than translation of polycistronic forms (Barkan et al. 1994; Sturm et al. 1994; Hirose and Sugiura 1997), intercistronic cleavage by endonucleases is required. Subsequently, 5' and 3' ends of cleaved products and of a priori monocistronic transcripts are modified by exonucleolytic and/or endonucleolytic trimming and polyadenylation. All these processes are dependent on nuclear-encoded proteins. Intercistronic cleavage is performed by endoribonucleases, which usually exhibit low sequence specificities, thus being supposed to be regulated by sequence-specific factors. RNase E (Schein et al. 2008) and RNase J (Li de la SierraGallay et al. 2008) are candidates for endonucleases involved in intercistronic cleavage of plastid transcripts. A PPR (PentatricoPeptide Repeat) family protein, CRR2 from Arabidopsis, also exhibits endoribonuclease activity in vitro (Okuda et al. 2009) but is specific to the rps7-ndhB intergenic region (Hashimoto et al. 2003).

So far, $5^{\prime}$ end formation of transcripts was believed to be accomplished via site-specific intercistronic cleavage by an endonuclease since no protein with $5^{\prime} \rightarrow 3^{\prime}$ exoribonuclease activity was known to be located in plastids. On the contrary, $3^{\prime}$ ends are supposed to be generated by the $3^{\prime} \rightarrow 5^{\prime}$ exoribonuclease activity of polynucleotide phosphorylase (PNPase). This enzyme is sensitive to secondary structures and arrests at $3^{\prime}$ terminal stem-loop structures (Yehudai-Resheff et al. 2001). Recently, however a 5' $\rightarrow 3^{\prime}$ exoribonuclease function was found for RNase $\mathrm{J}$ (Mathy et al. 2007) implying similar mechanisms for 3' and 5' end maturation. Some termini located in intergenic regions, e.g., atpI-atpH and petB-petD overlap after processing (Barkan et al. 1994; Pfalz et al. 2009) pointing to a role of $5^{\prime} \rightarrow 3^{\prime}$ exonucleolytic degradation of $5^{\prime}$ ends. Pfalz et al. (2009) and Prikryl et al. (2011) postulate that endonucleolytic cleavages in intergenic regions occur stochastically and sequences are trimmed exonucleolytically until a prescribed position is reached. This position is either denoted by the presence of a stem-loop structure or it is marked by specific RNA-binding proteins. In maize, the PPR10 protein was found to define $5^{\prime}$ and $3^{\prime}$ ends of processed psaJ-rpl33 or atpI-atpH intergenic regions, respectively (Pfalz et al. 2009). During binding to the $5^{\prime}$ end of atpH, PPR 10 also activates translation by releasing a ribosome-binding region from an RNA-duplex (Prikryl et al. 2011). Similar functions are suggested for other PPR- and TPR-like proteins specific for a diverse set of transcripts (Barkan 2011). The discovery of a set of small RNAs (sRNAs) accumulating in chloroplasts is consistent with a role of different proteins serving as "caps" for processed transcripts. These sRNAs are believed to be the binding sites of capping proteins since their positions within transcripts overall match the $5^{\prime}$ and $3^{\prime}$ ends of processed transcripts (Ruwe and Schmitz-Linneweber 2012; Zhelyazkova et al. 2012).

\section{RNA splicing}

Many plastid transcripts (mRNAs and tRNAs) harbor introns, which must be removed prior to translation. Depending on splicing mechanisms and primary and secondary structures, organellar introns are classified into group I and group II introns, respectively (Houghland et al. 2006; Pyle and Lambowitz 2006; Fedorova and Zingler 2007). Group II introns are sub-divided into group IIA to group IID, with only group IIA and IIB occurring in flowering plants (Michel et al. 1989).

Higher plant plastids exhibit only one group I intron located in the trnL transcript, whereas there are five in $C$. reinhardtii and even more in other Chlamydomonas species (Turmel et al. 1993). However, there is a set of about 20 group II introns conserved among higher plant organellar genomes (Schmitz-Linneweber and Barkan 2007). Originally, introns were mobile genetic elements encoding a maturase, which facilitates splicing of the host intron (Eickbush 1999; Wank et al. 1999). This ability has been widely lost in higher plants. The only remaining intronencoded maturase, MatK, is encoded by the $\operatorname{trnK}$ transcript and was found to co-immunopurify with all group IIA introns except clpP intron 2 (Zoschke et al. 2010). In fact, splicing of plastid introns is rather mediated by at least 12 nuclear-encoded proteins (de Longevialle et al. 2010).

Two main protein families were found in this context: CRM (Chloroplast RNA splicing and ribosome maturation; Barkan et al. 2007) domain proteins, which target introns from several genes (Stern et al. 2010), and PPR proteins (Schmitz-Linneweber and Small 2008) that seem to be generally specific to only one transcript (Stern et al. 2010). In addition, some proteins harboring different sequence motifs are involved in splicing.

However, despite the large number of splicing factors identified, there is no concrete mechanistic model for their function. It is hypothesized that one or more factors interact with introns in a sequence-specific manner and change their folding, thus enabling recognition by general splicing factors (de Longevialle et al. 2010). Whether this is the general mechanism of plastid intron splicing needs to be further elucidated. 


\section{RNA editing}

Editing is the process of modification of transcripts by altering individual nucleotides. It is a common mechanism in all plants, except liverworts (Freyer et al. 1997) and it is absent in algae and cyanobacteria. In general, cytidine (C) is exchanged to uridine (U) in chloroplasts, but in some hornworts and ferns $\mathrm{U}$ is converted into $\mathrm{C}$ (Kugita et al. 2003; Wolf et al. 2004). There are typically about 30 editing sites in plastids of vascular plants, e.g., Arabidopsis has 34 editing sites in 18 different genes (Tillich et al. 2005; Chateigner-Boutin and Small 2007). Editing often restores conserved amino acids required for protein function (Zito et al. 1997; Sugita et al. 2006) or creates new translation initiation codons (Hoch et al. 1991; Kudla et al. 1992; Neckermann et al. 1994).

The mechanism of editing is so far unknown. However, both, cis- and trans-acting elements have been proposed to play a role. On the cis-acting side sequence elements immediately upstream of the respective site are necessary, putatively serving as binding sites for trans-acting elements (Bock et al. 1996; Chaudhuri and Maliga 1996; Sasaki et al. 2006). Indeed, several exclusively nuclear-encoded transacting factors have been identified and all except one belong to the family of PPR proteins. CRR4, the first transacting factor to be identified, is required for editing of a $\mathrm{C}$ at position 2 in $n d h D$ transcripts and thus restoration of an AUG start codon (Kotera et al. 2005). It is the only factor that has been demonstrated to directly bind to its target editing site (Okuda et al. 2006, 2007). Like CCR4, the majority of trans-acting PPR proteins are specific to one transcript (Okuda et al. 2007; Zhou et al. 2009; Cai et al. 2009). However, five PPR proteins have been reported to target up to three editing sites, suggesting that editing factors must be able to distinguish pyrimidines from purines and sometimes even recognize specific bases (Hammani et al. 2009).

\section{Regulation of translation}

Translation of plastid transcripts is performed by bacterialtype $70 \mathrm{~S}$ ribosomes, in line with the prokaryotic origin of chloroplasts. Although there is a certain degree of conservation among translation factors and most ribosomal proteins, bacterial and plastid translation machineries differ (Beligni et al. 2004), e.g., by lack or divergence of some ribosomal proteins and gain of protein components for translational regulation of plastid gene expression (Zerges 2000; Beligni et al. 2004). Thus, both the large and the small ribosomal subunit also include nuclear-encoded plastid-specific ribosomal proteins (PSRP), which were characterized in spinach, Arabidopsis and Chlamydomonas plastids (Subramanian 1993; Yamaguchi et al. 2002, 2003;
Tiller et al. 2012). Also, several nuclear-encoded proteins from Chlamydomonas and higher plants have been identified as transcript-specific translational regulators. The function of some of these factors will be discussed later.

\section{Cis-acting elements in plastid transcripts}

Besides varying trans-acting factors, the organization of cis-elements displays a major difference between plastid and bacterial translation. In bacteria, translation is initiated by binding of the $3^{\prime}$ terminus of the 16S rRNA to the Shine-Dalgarno (SD) sequence (typically GGAGG) in the 5' UTR of the transcript. The SD sequence is located between 5 and 9 nucleotides upstream from the start codon and mediates correct positioning of the ribosome for translational initiation (Laursen et al. 2005; Yusupova et al. 2001). SD-like sequences can also be found in 5' UTRs of plastid transcripts, but they differ in position and sequence (Sugiura et al. 1998). While translation of some transcripts is dependent on SD-like sequences ( $r b c L$, atpE, and rps14 from tobacco; psbA from Chlamydomonas), other transcripts are only partially dependent (rps12 and pet $B$ from tobacco) or independent of them ( $p s b A$ and $a t p B$ from tobacco; petD, atpB, atpE, rps4, and rps7 from Chlamydomonas; Mayfield et al. 1994; Sakamoto et al. 1994; Hirose and Sugiura 1996; Fargo et al. 1998; Hirose and Sugiura 2004a, b). Interestingly, the rps 2 SD-like sequence from tobacco was even shown to be a negative regulatory element for translation (Plader and Sugiura 2003). The dispensability of SD-like sequences in 5' UTRs of plastid transcripts points to the existence of distinct regulatory ciselements.

As an example, the $5^{\prime}$ UTR of the $p s b A$ transcript in tobacco possesses a SD-like sequence located at $-33 \mathrm{nt}$ upstream of the start codon. In tobacco this element is dispensable for translation (Hirose and Sugiura 1996), which stands in contrast to the requirement of a SD-like sequence in Chlamydomonas psbA-translation (Mayfield et al. 1994). Indeed, three other elements within the 5' UTR of tobacco $p s b A$ have been identified: two sequences complementary to the $3^{\prime}$ terminus of chloroplast $16 \mathrm{~S}$ rRNA (RBS1 and RBS2) located at -9 and -22 nt upstream of the start codon, respectively and an $\mathrm{AU}$ rich sequence (UAAAUAAA) located between RBS1 and RBS2 (Hirose and Sugiura 1996). It is hypothesized that RBS1 and RBS2 interact cooperatively with the $3^{\prime}$ end of $16 \mathrm{~S}$ rRNA resulting in looping out of the AU rich sequence, which facilitates the interaction of trans-acting factors (Hirose and Sugiura 1996). Similar sequence elements have been described for the 5' UTR of psbD in Chlamydomonas, with a SD-like motif (PRB1) and the PRB2 site at -13 and $-30 \mathrm{nt}$ upstream of the start codon, respectively and a polyU-rich element located in between (Nickelsen et al. 
1999). Like the sequence elements from the $p s b A 5^{\prime}$ UTR, those of $p s b D$ are thought to serve as binding sites for trans-acting factors (Nickelsen et al. 1999; Ossenbühl and Nickelsen 2000). Other cis-elements affecting protein synthesis were found in the 5' UTRs of $p s b C$, petD and $r p s 7$ of Chlamydomonas (Zerges et al. 1997, 2003; Fargo et al. 1999; Higgs et al. 1999) and the atpB mRNA of tobacco (Hirose and Suigura 2004b) mainly in the context of targets for trans-acting factors.

\section{Trans-acting translational regulators}

Trans-acting factors of translation are encoded in the nucleus and are generally specific to single transcripts. As mentioned above, many factors that mediate transcript stability by binding to the 5'UTRs of their target transcripts are also proposed to assist in translation initiation by releasing ribosome-binding sites (Barkan 2011; Prikryl et al. 2011). These functions have been assigned to many PPR proteins like the above-mentioned PPR10, HCF152, CRP1, and PPR38 (for atpI-atpH, psbH-petB, petB-petD, and clpP-rps 12, respectively) that were identified in Arabidopsis, maize and the moss Physcomitrella patens (Meierhoff et al. 2003; Schmitz-Linneweber et al. 2005; Hattori et al. 2007; Hattori and Sugita 2009; Pfalz et al. 2009; Barkan 2011; Prikryl et al. 2011) and for the HAT (Half-A-Tetratricopeptide repeat) protein HCF107 of Arabidopsis and maize that regulates $p s b H$ transcript stability and translation (Felder et al. 2001; Sane et al. 2005; Hammani et al. 2012).

Besides general regulation of plastid translation, many trans-factors were described as modulating translation in a light- and assembly-dependent manner (Marin-Navaro et al. 2007). The best-studied mechanism of light-regulated translation was described for the $p s b A$ transcript in Chlamydomonas. A stem-loop structure in the 5' UTR (Mayfield et al. 1994) is bound by a complex of several proteins upon illumination. RB47 is a poly A-binding protein (cPAB1) whose binding to the $p s b A 5^{\prime} \mathrm{UTR}$ is enhanced under reducing conditions (Kim and Mayfield 1997; Yohn et al. 1998). Modulation of RNA-binding properties of CPAB 1 in response to the redox status of the cell is believed to be regulated by RB60 and TBA1, a putative protein disulfide isomerase (cPDI) and oxidoreductase homolog, respectively (Alergand et al. 2006; Kim and Mayfield 1997; Somanchi et al. 2005). In addition, ADPdependent phosphorylation of cPDI is presumed to control the RNA-binding capacity of cPAB1 (Danon and Mayfield 1994). Another protein, RB55, was identified as part of the complex bound to the $p s b A 5^{\prime}$ UTR, but it has not yet been cloned or characterized (Danon and Mayfield 1991). Finally, RB38, another RNA-binding protein, which functions independent of the redox status, was described to bind specifically to uridine-rich sequences of the $p s b A 5^{\prime} \mathrm{UTR}$ (Barnes et al. 2004). However, RB38 was found to be identical to RBP40 from Chlamydomonas, which is involved in $p s b D$-rather than $p s b A$-translation (Schwarz et al. 2007). RBP40 binds to the polyU-rich element of the $p s b D 5^{\prime} \mathrm{UTR}$ (Ossenbühl and Nickelsen 2000) and destabilizes the stemloop structure thereby enabling binding of the small ribosomal subunit to the initiation codon (Klinkert et al. 2006). Guidance of RBP40 to its target sequence is mediated by the stability factor NAC2, which, together with RBP40, is part of a high molecular weight complex of approximately $550 \mathrm{kDa}$ (Schwarz et al. 2007). As is the case for $p s b A$, translation of $p s b D$ is induced by light (Malnoe et al. 1988). A recent study provided evidence for a dynamic formation of the NAC2/RBP40 complex, which is based on an intermolecular disulfide bridge that is reduced in the dark causing dissociation of RBP40 from the complex and preventing translation initiation (Schwarz et al. 2012).

Besides light regulation, plastid translation can also be modulated by the assembly status of proteins into their respective complexes. This regulatory process is referred to as "Control by Epistasy of Synthesis" (CES) and has been reported for all four thylakoid membrane complexes (Choquet et al. 1998; Wostrikoff et al. 2004; Minai et al. 2006; Drapier et al. 2007). Regulation of the cytochrome $f$ subunit of the cytochrome $b_{6} f$ complex from Chlamydomonas is the best-studied process so far. When not assembled into the complex, cytochrome $f$ interacts with MCA1, which usually binds and stabilizes the petA transcript and interacts with the translational factor TCA1 (Raynaud et al. 2007; Boulouis et al. 2011). Interaction with unassembled cytochrome $f$ induces proteolysis of MCA1. This destabilizes the petA transcript and prevents its translation, which finally results in autoinhibition of cytochrome $f$ synthesis (Raynaud et al. 2007; Boulouis et al. 2011).

Regulation of translational initiation is clearly the most important step of plastid translation. However, elongation and termination also display targets for regulatory processes. Elongation of the D1 protein is regulated by light (Mühlbauer and Eichacker 1998; Zhang et al. 2000), the presence of co-factors (Mullet et al. 1990) and the availability of assembly partners (de Vitry et al. 1989). The nuclear-encoded factors VIR-115 from barley and AC115 from Chlamydomonas are assumed to stabilize translation intermediates of D1 or D2, respectively, and facilitate their folding, co-factor binding, and/or co-translational membrane insertion (Kim et al. 1994; Rattanachaikunsopon et al. 1999).

Recognition of stop codons and translational termination is dependent on release factors in both eukaryotes and prokaryotes. In bacteria, the release factors RF1 (prfA) decoding UAA and UAG and RF2 (prfB) decoding UAA and UGA have been identified (Scolnick et al. 1968; Nakamura and Ito 1998). In Arabidopsis, a homolog to prfB, 
AtPRFB1/HCF109, has been cloned and shown to be required for termination of transcripts with UGA and UAA stop codons and to regulate transcript stability and protein synthesis (Meurer et al. 2002).

\section{Post-translational regulation: protein maturation and complex assembly}

The last important steps of plastid gene expression include protein maturation, i.e., co-factor binding and proteolytic processing, and the assembly of all subunits to form an active complex. In addition, thylakoid membrane proteins have to be inserted into the lipid bilayer or transported across it. All of these processes can occur post- or co-translationally and are dependent on both general and complexspecific auxiliary factors.

\section{Membrane insertion}

Transport of complex subunits across or insertion into the thylakoid membrane is facilitated by four distinct pathways. Both the secretory (Sec) and twin-arginine-translocase (Tat) pathways transport proteins across the thylakoid membrane into the lumen. The "spontaneous" and the SRP pathways insert proteins into the membrane, the latter being specific to LHCP (light-harvesting chlorophyll binding) family proteins (Schünemann 2004; Luirink et al. 2005; Aldridge et al. 2009). Moreover, LHCP membrane insertion is dependent on the ALB3 translocase, which is the plastid homolog to the membrane insertion factors Oxa1p and YidC from mitochondria and Escherichia coli, respectively (Moore et al. 2000; Bellafiore et al. 2002; Kuhn et al. 2003). The SRP pathway is believed to recruit LHCPs from the stroma and target them to the membrane and ALB3 (Aldridge et al. 2009). ALB3 also interacts with the chloroplast SECY translocase (Klostermann et al. 2002; Pasch et al. 2005), which is believed to be involved in co-translational membrane insertion of the D1 protein (Zhang et al. 2001). Yeast split-ubiquitin and co-immunoprecipitation experiments revealed a direct interaction between ALB3 and subunits from PSII and PSI and the $\mathrm{CF}_{0} \mathrm{III}$ subunit from ATP synthase (Pasch et al. 2005; Göhre et al. 2006), indicating a general role of ALB3 in membrane insertion of proteins. The maturation and assembly of the thylakoid membrane complexes are likely mediated by more specific factors since each complex and each subunit exhibit different properties.

Post-translational modifications/subunit maturation

Maturation of plastid proteins may also involve their proteolytic truncation. The D1 subunit of the PSII reaction center is the best-known example for this mode of protein modification. D1 is synthesized as a precursor (pD1) with a C-terminal extension of nine amino acid residues in higher plants (Marder et al. 1984; Takahashi et al. 1988). During its integration into the thylakoid membrane, the D1 precursor is processed to its mature form by the nuclear-encoded lumenal carboxy-terminal processing protease (CtpA; Anbudurai et al. 1994; Fujita et al. 1995). Recently, additional components facilitating the processing of the D1 precursor protein have been identified in Synechocystis (PratA; Klinkert et al. 2004) and Arabidopsis (LPA19; Wei et al. 2010), although their precise function is not clear yet. C-terminal processing was reported to be a prerequisite for binding of the manganese cluster to PSII (Nixon et al. 1992; Roose and Pakrasi 2004).

Another aspect of protein maturation is the binding of co-factors. The photosynthetic complexes contain pigments for light harvesting and charge separation as well as redoxactive factors for electron transfer. PSII possesses several chlorophylls and xanthophylls, two pheophytins, two hemes, one manganese cluster, one bicarbonate, two $\mathrm{Ca}^{2+}$ ions, one $\mathrm{Fe}^{2+}$ ion, and one $\mathrm{Cl}^{-}$ion (Guskov et al. 2009). Similarly, PSI is associated with a large number of chlorophylls and xanthophylls, in line with the function of both photosystems in light harvesting. Redox reactions are facilitated by two phylloquinones and three [4Fe-4S] clusters (Amunts et al. 2007). Finally, the cytochrome $b_{6} f$ complex binds four hemes (two b- and c-type hemes each), one [2Fe-2S] cluster and one chlorophyll and xanthophyll each (Kurisu et al. 2003; Stroebel et al. 2003).

Plastid Fe-S clusters are assembled by machinery related to the eubacterial SUF (Sulfur Utilization Factor) system (Balk and Pilon 2011). Attachment of assembled clusters to their target proteins seems to require further components, such as scaffold and carrier/transfer proteins. So far, only two proteins have been identified that may play a role in [4Fe-4S] cluster binding to PSI: the Arabidopsis HCF101 protein and cyanobacterial RubA (Schöttler et al. 2011). Recombinant HCF101 was found to transiently bind [4Fe-4S] clusters and transfer them onto apoproteins (Schwenkert et al. 2010). Based on spectroscopic measurements using Synechococcus sp. mutant strains, RubA was hypothesized to be specifically required for incorporation of the $[4 \mathrm{Fe}-4 \mathrm{~S}]$ cluster associated with PsaAB ( $F_{x}$; Shen et al. 2002). Homologs of RubA are encoded by higher plant genomes but their function has not been elucidated so far.

As mentioned above, the cytochrome $b_{6} f$ complex is associated with four hemes. The two non-covalently bound b-type hemes are bound by the cytochrome $b_{6}$ polypeptide and are believed to bind spontaneously (Robertson et al. 1994). On the contrary, the two c-type hemes bind covalently to cytochrome $b_{6}$ and cytochrome $f$, respectively. 
For biogenesis of c-type cytochromes, four distinct pathways (system I-IV) have been characterized so far, although there is evidence for additional mechanisms (Allen et al. 2004; de Vitry 2011). System III, which occurs in mitochondria of fungi, vertebrates and invertebrates, is the simplest system and consists of a heme lyase as the single component (Dumont et al. 1987; Giegé et al. 2008). In contrast, systems I, II and IV are more complex. System I (or Ccm system) occurs in archaea, $\alpha$ - and $\gamma$-proteobacteria and the mitochondria of plants and red algae, and consists of up to 10 membrane-bound proteins (Allen et al. 2008; Sanders et al. 2010). System II operates in some gram-positive bacteria, cyanobacteria, some $\beta$-, $\delta$ - and $\varepsilon$-proteobacteria and plastids of plants and algae (Kranz et al. 2002). In plastids, it is required for the biogenesis of cytochromes $f$ and $c_{6}$ (Rurek 2008). Cytochrome $f$ possesses a classical $\mathrm{CXXCH}$ heme-binding motif whose two cysteines form thioether linkages with the vinyl groups of the heme. The apoprotein is synthesized in the plastid stroma but targeted to the electropositive thylakoid lumen in a Sec-dependent way (Rohl and van Wijk 2001), where the conversion of apo- to holo-cytochrome $f$ occurs. Ligation of heme to cytochrome $f$ requires several steps. The heme is synthesized in the stroma, and needs to be transported to the lumen. There it must be transferred to or kept in its reduced state to assure that the vinyl groups are chemically active. Similarly, the cysteine residues of the heme-binding motif in the cytochrome must be reduced to form thioether bonds to the heme vinyl groups (Kranz et al. 2009). At least six factors are involved in cytochrome $f$ (and $c_{6}$ ) maturation in Chlamydomonas: the nuclear-encoded proteins CCS1-CCS5, and the plastid-encoded CcsA (Howe and Merchant 1992; Xie and Merchant 1996, 1998; Inoue et al. 1997). CcsA and CCS1 (also: CCSB) are supposed to form a complex and function in heme delivery and its ligation to the apoprotein (Dreyfuss et al. 2003; Hamel et al. 2003). CcsA contains a "WWD" motif (WGX $\phi W X W D$, where $\phi$ is an aromatic residue) exposed to the lumen, which is also found in two system I components and is thought to transport heme into the thylakoid lumen and present it to the apocytochrome for ligation (Xie and Merchant 1996; Goldman et al. 1998; Rurek 2008; Kranz et al. 2009). CCS1, on the other hand, is supposed to chaperone reduced apocytochromes (Rurek 2008). HCF164, a thioredoxin-like protein from Arabidopsis was also found to be required for cytochrome $f$ maturation (Lennartz et al. 2001) and recently, CCS5 was described as its homolog in Chlamydomonas (Gabilly et al. 2010). Also, the thiol disulfide transporter homolog CCDA is required for cytochrome $f$ maturation in Arabidopsis but it has not yet been characterized in Chlamydomonas (Page et al. 2004). CCS5 and CCDA together with the recently discovered CCS4 protein seem to be involved in a thiooxidation/thioreduction pathway in which reducing equiva- lents are transferred to the electropositive side of the thylakoid membrane (lumen) and used for the reduction of apocytochromes (Rurek 2008; Gabilly et al. 2011).

In contrast to cytochrome $f$, cytochrome $b_{6}$ binds its $c$-type heme (heme $\mathrm{c}_{\mathrm{i}}$ ) on the electronegative, i.e., the stromal side of the thylakoid membrane, by only a single cysteine residue (Cys35; Kurisu et al. 2003; Stroebel et al. 2003). The maturation pathway mediating this atypical heme binding, the CCB system or system IV, requires at least four nuclear-encoded factors, CCB1-4, and is conserved among species performing oxygenic photosynthesis (Kuras et al. 2007; Lyska et al. 2007; Lezhneva et al. 2008; de Vitry 2011). Apparently, insertion of heme $c_{\mathrm{i}}$ to cytochrome $b_{6}$ occurs after binding of the non-covalent $b$-type hemes and requires several steps in which different $\mathrm{CCB}-\mathrm{CCB}$ and CCB-cytochrome $b_{6}$ complexes are formed (Saint-Marcoux et al. 2009). Since heme synthesis and incorporation into apocytochrome $b_{6}$ take place on the same side of the thylakoid membrane, no thioredox or translocation machinery is required and the $\mathrm{CCB}$ proteins are more likely to operate as a heme-chaperoning and -delivery system (de Vitry 2011). Conserved stroma-exposed tryptophan, tyrosine and/or phenylalanine residues in the $\mathrm{CCB}$ proteins that are expected to interact with heme (similar to the WWD motif in CcsA, see above) support this hypothesis (Kuras et al. 2007; de Vitry 2011). How the CCB proteins mediate heme attachment to apocytochrome $b_{6}$ and whether there are more, so far undiscovered factors participating in these processes still needs to be elucidated in future studies.

\section{Assembly of complexes}

Assembly of thylakoid membrane complexes is accomplished in a step-by-step manner. Usually, one protein serves as an anchor or scaffold for subsequent assembly steps. For PSII, a complex consisting of the D2 protein and the $\alpha$ and $\beta$ subunits of cytochrome $b_{559}$ seems to be the initiation point of assembly (Komenda et al. 2004; Rokka et al. 2005; Minai et al. 2006). Subsequently, the D1 and PsbI proteins are attached to form the reaction center (RCII; Rokka et al. 2005; Minai et al. 2006; Dobáková et al. 2007). The addition of the inner antenna protein CP47 leads to the formation of the RC47 complex and facilitates binding of several small subunits like the phosphoprotein PsbH (Komenda et al. 2004; Rokka et al. 2005; Minai et al. 2006). After incorporation of CP43 the monomeric core complex is complete and assembly of the manganese cluster and oxygen-evolving complex can occur, as well as dimerization and supercomplex formation (Rokka et al. 2005). A multitude of assembly-assisting proteins has been identified for PSII, although their mode of action is largely unknown. LPA1 from Arabidopsis is an intrinsic membrane protein and is thought to function as a chaperone for PSII 
assembly by interaction with D1 (Peng et al. 2006). Another protein, PAM68 is assumed to associate with LPA1 and D1 in an early intermediate complex (Armbruster et al. 2010). Folding and/or assembly of CP43 into PSII depends on the ALB3 interacting proteins LPA2 and LPA3 (Ma et al. 2007; Cai et al. 2010). Similarly, HCF136 is involved in a very early assembly step of PSII since in absence of this factor, PSII subunits are synthesized but no stable complexes can be detected (Meurer et al. 1998; Plücken et al. 2002). At the level of supercomplex formation AtFKBP20-2, a lumenal immunophilin, and Psb29 were reported to play a role (Keren et al. 2005; Lima et al. 2006).

PSII is not only synthesized de novo, but it is constantly renewed due to photooxidative damage (Aro et al. 1993). The D1 protein is the major target of the PSII repair cycle (Mattoo et al. 1981; Ohad et al. 1990). Damaged PSII complexes are phosphorylated and migrate from the grana to the stoma lamellae, where D1 is degraded and replaced by a newly synthesized protein (Mulo et al. 2008). Degradation is predominantly mediated by FtsH and Deg proteases that act in a cooperative manner (Kato and Sakamoto 2009; Kato et al. 2012) and apparently the lumenal AtTLP18.3 protein is involved in degradation of D1, but also in dimerization of PSII reaction centers (Sirpiö et al. 2007). Chlorophyll released during repair may be bound by ELIP proteins in higher plants, which belong to the LIL (light-harvestinglike) protein family (Hutin et al. 2003). Reassembly of PSII is assumed to require the abovementioned general assembly factors in addition to repair-specific factors, like Hsp70 proteins and PPL1 (Ishihara et al. 2007; Mulo et al. 2008).

In contrast to the large number of auxiliary factors for assembly of PSII, only a few proteins have been identified in conjunction with PSI and the cytochrome $b_{6} f$ complex. The starting point for cytochrome $b_{6} f$ complex assembly is cytochrome $b_{6}$, which rapidly interacts with subunit IV. This dimer is a prerequisite for cytochrome $f$ binding and subsequent assembly of the small subunits PetG, PetL, PetM, and PetN. The Rieske protein appears to be bound only loosely to the complex and is likely to contribute to dimer stability, which is the active form of the cytochrome $b_{6} f$ complex (Choquet and Vallon 2000; Kurisu et al. 2003; Stroebel et al. 2003). Biogenesis factors have only been identified in the context of (1) processing and/or stabilization of transcripts, (2) CES autoregulation of cytochrome $f$, and (3) co-factor binding, which is important for protein stability (Kuras et al. 1995; de Vitry et al. 2004). HCF153 from Arabidopsis is probably involved in assembly of the cytochrome $b_{6} f$ complex, because mutants exhibit drastically reduced amounts of the major subunits, while their translation is not impaired (Lennartz et al. 2006). However, the molecular function has yet not been revealed.
PSI assembly is initiated by the co-translational insertion of PsaA and PsaB, which then bind to their co-factors to form the PsaAB reaction center. Subsequently, PsaC with its two $[4 \mathrm{Fe}-4 \mathrm{~S}]$ clusters is attached, followed by PsaD, PsaE and other subunits (Schöttler et al. 2011). The nuclear-encoded subunits PsaK and PsaG apparently bind to PSI after association of the PSI core and LHCI complexes and stabilize this interaction (Ozawa et al. 2010). Besides the true components of PSI that assist in complex assembly, only a small number of auxiliary proteins were identified so far (Schöttler et al. 2011). Two plastidencoded proteins, Ycf3 and Ycf4, are both essential for PSI accumulation in Chlamydomonas (Boudreau et al. 1997). In tobacco, ycf4 mutants maintain photoautotrophic growth although they are severely affected in their photosynthetic capacity (Krech et al. 2012). In addition, two nuclearencoded proteins were found to be essential for PSI accumulation in higher plants: a Ycf3-interacting protein (Y3IP1) (Albus et al. 2010) and Pyg7-1 whose function has not been clearly defined yet (Stöckel et al. 2006).

\section{Conclusion}

The chloroplast is a semiautonomous cell organelle of prokaryotic origin embedded into the environment of a eukaryotic cell. In order to allow proper chloroplast development and its adjustment to endo and exogenous stimuli, the nucleus provides a large number of factors that regulate different processes inside the chloroplast (Fig. 1). In this article, we gave an overview of the different steps in chloroplast gene expression and in the assembly of the photosynthetic thylakoid membrane complexes and the ways they are regulated predominantly by nuclear-encoded proteins. Even though more and more of these factors are identified, e.g. through forward genetic screens and mass spectrometric approaches, the precise modes of action are still largely unknown. However, some of these mechanisms are about to be understood, and it becomes more and more clear that chloroplast gene expression as well as complex assembly are highly dynamic processes. We have only begun to understand how light quality and quantity, availability of nutrients, and developmental and stress signals take influence on the processes inside the chloroplast. Uncovering all the different regulatory mechanisms will be an exciting challenge for future research.

Acknowledgments The authors acknowledge support from the German Science Foundation (DFG) through SFB-TR1.

Open Access This article is distributed under the terms of the Creative Commons Attribution License which permits any use, distribution, and reproduction in any medium, provided the original author(s) and the source are credited. 


\section{References}

Albus CA, Ruf S, Schöttler MA, Lein W, Kehr J, Bock R (2010) Y3IP1, a nucleus-encoded thylakoid protein, cooperates with the plastid-encoded Ycf3 protein in photosystem I assembly of tobacco and Arabidopsis. Plant Cell 22:2838-2855

Aldridge C, Cain P, Robinson C (2009) Protein transport in organelles: protein transport into and across the thylakoid membrane. FEBS J 276:1177-1186

Alergand T, Peled-Zehavi H, Katz Y, Danon A (2006) The chloroplast protein disulfide isomerase RB60 reacts with a regulatory disulfide of the RNA-binding protein RB47. Plant Cell Physiol 47:540-548

Allen JW, Ginger ML, Ferguson SJ (2004) Complexity and diversity in $c$-type cytochrome biogenesis systems. Biochem Soc Trans 33:145-146

Allen JW, Jackson AP, Rigden DJ, Willis AC, Ferguson SJ, Ginger ML (2008) Order within a mosaic distribution of mitochondrial $c$-type cytochrome biogenesis systems? FEBS J 275:2385-2402

Amunts A, Drory O, Nelson N (2007) The structure of a plant photosystem I supercomplex at $3.4 \AA$ resolution. Nature 447:58-63

Anbudurai PR, Mor TS, Ohad I, Shestakov SV, Pakrasi HB (1994) The $c t p A$ gene encodes the $\mathrm{C}$-terminal processing protease for the $\mathrm{D} 1$ protein of the photosystem II reaction center complex. Proc Natl Acad Sci USA 91:8082-8086

Armbruster U, Zühlke J, Rengstl B, Kreller R, Makarenko E, Rühle T, Schünemann D, Jahns P, Weisshaar B, Nickelsen J, Leister D (2010) The Arabidopsis thylakoid protein PAM68 is required for efficient D1 biogenesis and photosystem II assembly. Plant Cell 22:3439-3460

Aro EM, Virgin I, Andersson B (1993) Photoinhibition of photosystem II. Inactivation, protein damage and turnover. Biochim Biophys Acta 1143:113-134

Azevedo J, Courtois F, Lerbs-Mache S (2006) Sub-plastidial localization of two different phage-type RNA polymerases in spinach chloroplasts. Nucleic Acids Res 34:436-444

Balk J, Pilon M (2011) Ancient and essential: the assembly of iron-sulfur clusters in plants. Trends Plant Sci 16:218-226

Barkan A (2011) Expression of plastid genes: organelle-specific elaborations on a prokaryotic scaffold. Plant Physiol 155:1520 1532

Barkan A, Walker M, Nolasco M, Johnson D (1994) A nuclear mutation in maize blocks the processing and translation of several chloroplast mRNAs and provides evidence for the differential translation of alternative mRNA forms. EMBO J 13:3170-3181

Barkan A, Klipcan L, Ostersetzer O, Kawamura T, Asakura Y, Watkins KP (2007) The CRM domain: an RNA binding module derived from an ancient ribosome-associated protein. RNA 13:55-64

Barnes D, Cohen A, Bruick RK, Kantardjieff K, Fowler S, Efuet E, Mayfield SP (2004) Identification and characterization of a novel RNA binding protein that associates with the $5^{\prime}$-untranslated region of the chloroplast $p s b A$ mRNA. Biochemistry 43:85418550

Beligni MV, Yamaguchi K, Mayfield SP (2004) The translational apparatus of Chlamydomonas reinhardtii chloroplast. Photosynth Res 82:315-325

Bellafiore S, Ferris P, Naver H, Göhre V, Rochaix JD (2002) Loss of Albino3 leads to the specific depletion of the light-harvesting system. Plant Cell 14:2303-2314

Bligny M, Courtois F, Thaminy S, Chang CC, Lagrange T, BaruahWolff J, Stern D, Lerbs-Mache S (2000) Regulation of plastid rDNA transcription by interaction of CDF2 with two different RNA polymerases. EMBO J 19:1851-1860

Bock R, Hermann M, Kössel H (1996) In vivo dissection of cis-acting determinants for plastid RNA editing. EMBO J 15:5052-5059
Boudreau E, Takahashi Y, Lemieux C, Turmel M, Rochaix JD (1997) The chloroplast $y c f 3$ and $y c f 4$ open reading frames of Chlamydomonas reinhardtii are required for the accumulation of the photosystem I complex. EMBO J 16:6095-6104

Boulouis A, Raynaud C, Bujaldon S, Aznar A, Wollman FA, Choquet Y (2011) The nucleus-encoded trans-acting factor MCA1 plays a critical role in the regulation of cytochrome $f$ synthesis in Chlamydomonas chloroplasts. Plant Cell 23:333-349

Cahoon AB, Harris FM, Stern DB (2004) Analysis of developing maize plastids reveals two mRNA stability classes correlating with RNA polymerase type. EMBO Rep 5:801-806

Cai W, Ji D, Peng L, Guo J, Ma J, Zou M, Lu C, Zhang L (2009) LPA66 is required for editing $p s b F$ chloroplast transcripts in Arabidopsis. Plant Physiol 150:1260-1271

Cai W, Ma J, Chi W, Zou M, Guo J, Lu C, Zhang L (2010) Cooperation of LPA3 and LPA2 is essential for photosystem II assembly in Arabidopsis. Plant Physiol 154:109-120

Carter ML, Smith AC, Kobayashi H, Purton S, Herrin DL (2004) Structure, circadian regulation and bioinformatic analysis of the unique sigma factor gene in Chlamydomonas reinhardtii. Photosynth Res 82:339-349

Chateigner-Boutin AL, Small I (2007) A rapid high-throughput method for the detection and quantification of RNA editing based on high-resolution melting of amplicons. Nucleic Acids Res 35:e114

Chaudhuri S, Maliga P (1996) Sequences directing C to U editing of the plastid $p s b L$ mRNA are located within a 22 nucleotide segment spanning the editing site. EMBO J 15:5958-5964

Choquet Y, Vallon O (2000) Synthesis, assembly and degradation of thylakoid membrane proteins. Biochimie 82:615-634

Choquet Y, Stern DB, Wostrikoff K, Kuras R, Girard-Bascou J, Wollman FA (1998) Translation of cytochrome $f$ is autoregulated through the $5^{\prime}$ untranslated region of petA mRNA in Chlamydomonas chloroplasts. Proc Natl Acad Sci USA 95:4380-4385

Courtois F, Merendino L, Demarsy E, Mache R, Lerbs-Mache S (2007) Phage-type RNA polymerase RPOTmp transcribes the $r r n$ operon from the PC promoter at early developmental stages in Arabidopsis. Plant Physiol 145:712-721

Danon A, Mayfield SP (1991) Light regulated translational activators: identification of chloroplast gene specific mRNA binding proteins. EMBO J 10:3993-4001

Danon A, Mayfield SP (1994) ADP-dependent phosphorylation regulates RNA-binding in vitro: implications in light-modulated translation. EMBO J 13:2227-2235

de Longevialle AF, Small ID, Lurin C (2010) Nuclearly encoded splicing factors implicated in RNA splicing in higher plant organelles. Mol Plant 3:691-705

de Vitry C (2011) Cytochrome $c$ maturation system on the negative side of bioenergetic membranes: cCB or System IV. FEBS J 278:4189-4197

de Vitry C, Olive J, Drapier D, Recouvreur M, Wollman FA (1989) Posttranslational events leading to the assembly of photosystem II protein complex: a study using photosynthesis mutants from Chlamydomonas reinhardtii. J Cell Biol 109:991-1006

de Vitry C, Desbois A, Redeker V, Zito F, Wollman FA (2004) Biochemical and spectroscopic characterization of the covalent binding of heme to cytochrome $b_{6}$. Biochemistry 43:3956-3968

Demarsy E, Courtois F, Azevedo J, Buhot L, Lerbs-Mache S (2006) Building up of the plastid transcriptional machinery during germination and early plant development. Plant Physiol 142:993-1003

Dobáková M, Tichy M, Komenda J (2007) Role of the PsbI protein in photosystem II assembly and repair in the cyanobacterium Synechocystis sp. PCC 6803. Plant Physiol 145:1681-1691

Drapier D, Rimbault B, Vallon O, Wollman FA, Choquet Y (2007) Intertwined translational regulations set uneven stoichiometry of chloroplast ATP synthase subunits. EMBO J 26:3581-3591 
Dreyfuss BW, Hamel PP, Nakamoto SS, Merchant S (2003) Functional analysis of a divergent system II protein, Ccs1, involved in $c$-type cytochrome biogenesis. J Biol Chem 278:2604-2613

Dumont ME, Ernst JF, Hampsey DM, Sherman F (1987) Identification and sequence of the gene encoding cytochrome $c$ heme lyase in the yeast Saccharomyces cerevisiae. EMBO J 6:235-241

Eickbush TH (1999) Mobile introns: retrohoming by complete reverse splicing. Curr Biol 9:R11-R14

Fargo DC, Zhang M, Gillham NW, Boynton JE (1998) Shine-Dalgarno-like sequences are not required for translation of chloroplast mRNAs in Chlamydomonas reinhardtii chloroplasts or in Escherichia coli. Mol Gen Genet 257:271-282

Fargo DC, Boynton JE, Gillham NW (1999) Mutations altering the predicted secondary structure of a chloroplast 5 ' untranslated region affect its physical and biochemical properties as well as its ability to promote translation of reporter mRNAs both in the Chlamydomonas reinhardtii chloroplast and in Escherichia coli. Mol Cell Biol 19:6980-6990

Fedorova O, Zingler N (2007) Group II introns: structure, folding and splicing mechanism. Biol Chem 388:665-678

Felder S, Meierhoff K, Sane AP, Meurer J, Driemel C, Plücken H, Klaff P, Stein B, Bechtold N, Westhoff P (2001) The nucleus-encoded HCF 107 gene of Arabidopsis provides a link between intercistronic RNA processing and the accumulation of translation-competent $p s b H$ transcripts in chloroplasts. Plant Cell 13:2127-2141

Finkemeier I, Leister D (2010) Plant chloroplasts and other plastids. In: Encyclopedia of life sciences (eLS), Wiley, Chichester

Freyer R, Kiefer-Meyer MC, Kössel H (1997) Occurrence of plastid RNA editing in all major lineages of land plants. Proc Natl Acad Sci USA 94:6285-6290

Fujita S, Inagaki N, Yamamoto Y, Taguchi F, Matsumoto A, Satoh K (1995) Identification of the carboxy-terminal processing protease for the D1 precursor protein of the photosystem II reaction center of spinach. Plant Cell Physiol 36:1169-1177

Gabilly ST, Dreyfuss BW, Karamoko M, Corvest V, Kropat J, Page MD, Merchant SS, Hamel PP (2010) CCS5, a thioredoxin-like protein involved in the assembly of plastid $c$-type cytochromes. J Biol Chem 285:29738-29749

Gabilly ST, Kropat J, Karamoko M, Page MD, Nakamoto SS, Merchant SS, Hamel PP (2011) A novel component of the disulfide-reducing pathway required for cytochrome $c$ assembly in plastids. Genetics 187:793-802

Giegé P, Grienenberger JM, Bonnard G (2008) Cytochrome $c$ biogenesis in mitochondria. Mitochondrion 8:61-73

Göhre V, Ossenbühl F, Crèvecoeur M, Eichacker LA, Rochaix JD (2006) One of two Alb3 proteins is essential for the assembly of the photosystems and for cell survival in Chlamydomonas. Plant Cell 18:1454-1466

Goldman BS, Beck DL, Monika EM, Kranz RG (1998) Transmembrane heme delivery systems. Proc Natl Acad Sci USA 95:5003-5008

Guskov A, Kern J, Gabdulkhakov A, Broser M, Zouni A, Saenger W (2009) Cyanobacterial photosystem II at $2.9 \AA$ resolution and the role of quinones, lipids, channels and chloride. Nat Struct Mol Biol 16:334-342

Hajdukiewicz PT, Allison LA, Maliga P (1997) The two RNA polymerases encoded by the nuclear and the plastid compartments transcribe distinct groups of genes in tobacco plastids. EMBO J 16:4041-4048

Hamel PP, Dreyfuss BW, Xie Z, Gabilly ST, Merchant S (2003) Essential histidine and tryptophan residues in CcsA, a system II polytopic cytochrome $c$ biogenesis protein. J Biol Chem 278: 2593-2603

Hammani K, Okuda K, Tanz SK, Chateigner-Boutin AL, Shikanai T, Small I (2009) A study of new Arabidopsis chloroplast RNA editing mutants reveals general features of editing factors and their target sites. Plant Cell 21:3686-3699
Hammani K, Cook WB, Barkan A (2012) RNA binding and RNA remodeling activities of the half-a-tetratricorepeat (HAT) protein HCF107. Proc Natl Acad Sci USA 109:5651-5656

Harley CB, Reynolds RP (1987) Analysis of E. coli promoter sequences. Nucleic Acids Res 15:2343-2361

Hashimoto M, Endo T, Peltier G, Tasaka M, Shikanai T (2003) A nucleus-encoded factor, CRR2, is essential for the expression of chloroplast $n d h B$ in Arabidopsis. Plant J 36:541-549

Hattori M, Sugita M (2009) A moss pentatricopeptide repeat protein binds to the $3^{\prime}$ end of plastid clpP pre-mRNA and assists with mRNA maturation. FEBS J 276:5860-5869

Hattori M, Miyake H, Sugita M (2007) A pentatricopeptide repeat protein is required for RNA processing of $c l p P$ pre-mRNA in moss chloroplasts. J Biol Chem 282:10773-10782

Hedtke B, Börner T, Weihe A (1997) Mitochondrial and chloroplast phage-type RNA polymerases in Arabidopsis. Science 277:809-811

Hedtke B, Börner T, Weihe A (2000) One RNA polymerase serving two genomes. EMBO Rep 1:435-440

Herrmann RG, Westhoff P, Alt J, Tittgen J, Nelson N (1985) Thylakoid membrane proteins and their genes. In: van Vloten-Doting L, Groot GSP, Hall TC (eds) Molecular form and function of the plant genome. Plenum Publishing Corporation, New York, pp 233-256

Herrmann RG, Westhoff P, Link G (1992) Biogenesis of plastids in higher plants. In: Herrmann RG (ed) Plant gene research: cell organelles. Springer, Vienna, pp 275-349

Higgs DC, Shapiro RS, Kindle KL, Stern DB (1999) Small cis-acting sequences that specify secondary structures in a chloroplast mRNA are essential for RNA stability and translation. Mol Cell Biol 19:8479-8491

Hirose T, Sugiura M (1996) Cis-acting elements and trans-acting factors for accurate translation of chloroplast $p s b A$ mRNAs: development of an in vitro translation system from tobacco chloroplasts. EMBO J 15:1687-1695

Hirose T, Sugiura M (1997) Both RNA editing and RNA cleavage are required for translation of tobacco chloroplast $n d h D$ mRNA: a possible regulatory mechanism for the expression of a chloroplast operon consisting of functionally unrelated genes. EMBO J $16: 6804-6811$

Hirose T, Sugiura M (2004a) Functional Shine-Dalgarno-like sequences for translational initiation of chloroplast mRNAs. Plant Cell Physiol 45:114-117

Hirose T, Sugiura M (2004b) Multiple elements required for translation of plastid atpB mRNA lacking the Shine-Dalgarno sequence. Nucleic Acids Res 32:3503-3510

Hoch B, Maier RM, Appel K, Igloi GL, Kössel H (1991) Editing of a chloroplast mRNA by creation of an initiation codon. Nature 353:178-180

Houghland JL, Piccirilli JA, Forconi M, Jihee L, Herschlag D (2006) How the group I intron works: A case study of RNA structure and function. In: Gesteland RF, Cech TR, Atkins JF (eds) The RNA world, 3rd end. Cold Spring Harbor Lab, Cold Spring Harbor, pp 133-205

Howe G, Merchant S (1992) The biosynthesis of membrane and soluble plastidic $c$-type cytochromes of Chlamydomonas reinhardtii is dependent on multiple common gene products. EMBO J 11:2789-2801

Hutin C, Nussaume L, Moise N, Moya I, Kloppstech K, Havaux M (2003) Early light-induced proteins protect Arabidopsis from photooxidative stress. Proc Natl Acad Sci USA 100:4921-4926

Inoue K, Dreyfuss BW, Kindle KL, Stern DB, Merchant S, Sodeinde OA (1997) Ccs 1, a nuclear gene required for the post-translational assembly of chloroplast $c$-type cytochromes. J Biol Chem 272:31747-31754

Ishihama A (1988) Promoter selectivity of prokaryotic RNA polymerases. Trends Genet 4:282-286 
Ishihara S, Takabayashi A, Ido K, Endo T, Ifuku K, Sato F (2007) Distinct functions for the two PsbP-like proteins PPL1 and PPL2 in the chloroplast thylakoid lumen of Arabidopsis. Plant Physiol 145:668-679

Ishizaki Y, Tsunoyama Y, Hatano K, Ando K, Kato K, Shinmyo A, Kobori M, Takeba G, Nakahira Y, Shiina T (2005) A nuclearencoded sigma factor, Arabidopsis SIG6, recognizes sigma-70 type chloroplast promoters and regulates early chloroplast development in cotyledons. Plant J 42:133-144

Kaneko T, Sato S, Kotani H, Tanaka A, Asamizu E, Nakamura Y, Miyajima N, Hirosawa M, Sugiura M, Sasamoto S, Kimura T, Hosouchi T, Matsuno A, Muraki A, Nakazaki N, Naruo K, Okumura S, Shimpo S, Takeuchi C, Wada T, Watanabe A, Yamada M, Yasuda M, Tabata S (1996) Sequence analysis of the genome of the unicellular cyanobacterium Synechocystis sp. strain PCC6803. II. Sequence determination of the entire genome and assignment of potential protein-coding regions (supplement). DNA Res 3:185-209

Kaneko T, Nakamura Y, Wolk CP, Kuritz T, Sasamoto S, Watanabe A, Iriguchi M, Ishikawa A, Kawashima K, Kimura T, Kishida Y, Kohara M, Matsumoto M, Matsuno A, Muraki A, Nakazaki N, Shimpo S, Sugimoto M, Takazawa M, Yamada M, Yasuda M, Tabata S (2001) Complete genomic sequence of the filamentous nitrogen-fixing cyanobacterium Anabaena sp. strain PCC 7120. DNA Res 8(205-213):227-253

Kato Y, Sakamoto W (2009) Protein quality control in chloroplasts: a current model of D1 protein degradation in the photosystem II repair cycle. J Biochem 146:463-469

Kato Y, Sun X, Zhang L, Sakamoto W (2012) Cooperative D1 degradation in the photosystem II repair mediated by chloroplastic proteases in Arabidopsis. Plant Physiol 159:1428-1439

Keren N, Ohkawa H, Welsh EA, Liberton M, Pakrasi HB (2005) Psb29, a conserved 22-kD protein, functions in the biogenesis of photosystem II complexes in Synechocystis and Arabidopsis. Plant Cell 17:2768-2781

Kim J, Mayfield SP (1997) Protein disulfide isomerase as a regulator of chloroplast translational activation. Science 278:1954-1957

Kim J, Klein PG, Mullet JE (1994) Vir-115 gene product is required to stabilize D1 translation intermediates in chloroplasts. Plant Mol Biol 25:459-467

Kleine T, Voigt C, Leister D (2009) Plastid signalling to the nucleus: messengers still lost in the mists? Trends Genet 25:185-192

Klinkert B, Ossenbühl F, Sikorski M, Berry S, Eichacker L, Nickelsen J (2004) PratA, a periplasmic tetratricopeptide repeat protein involved in biogenesis of photosystem II in Synechocystis sp. PCC 6803. J Biol Chem 279:44639-44644

Klinkert B, Elles I, Nickelsen J (2006) Translation of chloroplast $p s b D$ mRNA in Chlamydomonas is controlled by a secondary RNA structure blocking the AUG start codon. Nucleic Acids Res 34:386-394

Klostermann E, Droste Gen Helling I, Carde JP, Schünemann D (2002) The thylakoid membrane protein ALB3 associates with the cpSecY-translocase in Arabidopsis thaliana. Biochem J 368:777-781

Komenda J, Reisinger V, Müller BC, Dobáková M, Granvogl B, Eichacker LA (2004) Accumulation of the D2 protein is a key regulatory step for assembly of the photosystem II reaction center complex in Synechocystis PCC 6803. J Biol Chem 279:48620-48629

Kotera E, Tasaka M, Shikanai T (2005) A pentatricopeptide repeat protein is essential for RNA editing in chloroplasts. Nature 433:326330

Kranz RG, Beckett CS, Goldman BS (2002) Genomic analyses of bacterial respiratory and cytochrome $c$ assembly systems: bordetella as a model for the system II cytochrome $c$ biogenesis pathway. Res Microbiol 153:1-6

Kranz RG, Richard-Fogal C, Taylor JS, Frawley ER (2009) Cytochrome $c$ biogenesis: mechanisms for covalent modifications and trafficking of heme and for heme-iron redox control. Microbiol Mol Biol Rev 73:510-528

Krech K, Ruf S, Masduki FF, Thiele W, Bednarczyk D, Albus CA, Tiller N, Hasse C, Schöttler MA, Bock R (2012) The plastid genome-encoded Ycf4 protein functions as a nonessential assembly factor for photosystem I in higher plants. Plant Physiol 159:579-591

Kudla J, Igloi GL, Metzlaff M, Hagemann R, Kössel H (1992) RNA editing in tobacco chloroplasts leads to the formation of a translatable $p s b L$ mRNA by a $\mathrm{C}$ to $\mathrm{U}$ substitution within the initiation codon. EMBO J 11:1099-1103

Kugita M, Yamamoto Y, Fujikawa T, Matsumoto T, Yoshinaga K (2003) RNA editing in hornwort chloroplasts makes more than half the genes functional. Nucleic Acids Res 31:2417-2423

Kuhn A, Stuart R, Henry R, Dalbey RE (2003) The Alb3/Oxa1/YidC protein family: membrane-localized chaperones facilitating membrane protein insertion? Trends Cell Biol 13:510-516

Kühn K, Weihe A, Börner T (2005) Multiple promoters are a common feature of mitochondrial genes in Arabidopsis. Nucleic Acids Res 33:337-346

Kuras R, Büschlen S, Wollman FA (1995) Maturation of pre-apocytochrome $f$ in vivo. A site-directed mutagenesis study in Chlamydomonas reinhardtii. J Biol Chem 270:27797-27803

Kuras R, Saint-Marcoux D, Wollman FA, de Vitry C (2007) A specific $c$-type cytochrome maturation system is required for oxygenic photosynthesis. Proc Natl Acad Sci USA 104:9906-9910

Kurisu G, Zhang H, Smith JL, Cramer WA (2003) Structure of the cytochrome $b_{6} f$ complex of oxygenic photosynthesis: tuning the cavity. Science 302:1009-1014

Laursen BS, Sorensen HP, Mortensen KK, Sperling-Petersen HU (2005) Initiation of protein synthesis in bacteria. Microbiol Mol Biol Rev 69:101-123

Leister D (2003) Chloroplast research in the genomic age. Trends Genet 19:47-56

Lennartz K, Plücken H, Seidler A, Westhoff P, Bechtold N, Meierhoff $\mathrm{K}$ (2001) HCF 164 encodes a thioredoxin-like protein involved in the biogenesis of the cytochrome $b_{6} f$ complex in Arabidopsis. Plant Cell 13:2539-2551

Lennartz K, Bossmann S, Westhoff P, Bechtold N, Meierhoff K (2006) HCF153, a novel nuclear-encoded factor necessary during a posttranslational step in biogenesis of the cytochrome $b_{6} f$ complex. Plant J 45:101-112

Lerbs-Mache S (1993) The 110-kDa polypeptide of spinach plastid DNA-dependent RNA polymerase: single-subunit enzyme or catalytic core of multimeric enzyme complexes? Proc Natl Acad Sci USA 90:5509-5513

Lerbs-Mache S (2011) Function of plastid sigma factors in higher plants: regulation of gene expression or just preservation of constitutive transcription? Plant Mol Biol 76:235-249

Lezhneva L, Kuras R, Ephritikhine G, de Vitry C (2008) A novel pathway of cytochrome $c$ biogenesis is involved in the assembly of the cytochrome $b_{6} f$ complex in Arabidopsis chloroplasts. J Biol Chem 283:24608-24616

Li de la Sierra-Gallay IL, Zig L, Jamalli A, Putzer H (2008) Structural insights into the dual activity of RNase J. Nat Struct Mol Biol $15: 206-212$

Liere K, Börner T (2007) Transcription and transcriptional regulation in plastids. In: Bock R (ed). Topics in Current Genetics 32:121174

Lima A, Lima S, Wong JH, Phillips RS, Buchanan BB, Luan S (2006) A redox-active FKBP-type immunophilin functions in accumulation of the photosystem II supercomplex in Arabidopsis thaliana. Proc Natl Acad Sci USA 103:12631-12636

Lonetto M, Gribskov M, Gross CA (1992) The sigma 70 family: sequence conservation and evolutionary relationships. J Bacteriol 174:3843-3849 
Loschelder H, Schweer J, Link B, Link G (2006) Dual temporal role of plastid sigma factor 6 in Arabidopsis development. Plant Physiol 142:642-650

Luirink J, von Heijne G, Houben E, de Gier JW (2005) Biogenesis of inner membrane proteins in Escherichia coli. Annu Rev Microbiol 59:329-355

Lysenko EA (2007) Plant sigma factors and their role in plastid transcription. Plant Cell Rep 26:845-859

Lyska D, Paradies S, Meierhoff K, Westhoff P (2007) HCF208, a homolog of Chlamydomonas CCB2 is required for accumulation of native cytochrome $b_{6}$ in Arabidopsis thaliana. Plant Cell Physiol 48:1737-1746

Ma J, Peng L, Guo J, Lu Q, Lu C, Zhang L (2007) LPA2 is required for efficient assembly of photosystem II in Arabidopsis thaliana. Plant Cell 19:1980-1993

Maier UG, Bozarth A, Funk HT, Zauner S, Rensing SA, SchmitzLinneweber C, Börner T, Tillich M (2008) Complex chloroplast RNA metabolism: just debugging the genetic programme? BMC Biol 6:36

Majeran W, Friso G, Barneche Y, Qu X, Huang M, Ponnala L, Watkins KP, Barkan A, van Wijk KJ (2012) Nucleoid-enriched proteomes in developing plastids and chloroplasts from maize leaves: a new conceptual framework for nucleoid functions. Plant Physiol 158:156-189

Maliga P (1998) Two plastid RNA polymerases of higher plants: an evolving story. Trends Plant Sci 3:4-6

Malnoe P, Mayfield SP, Rochaix JD (1988) Comparative analysis of the biogenesis of photosystem II in the wild-type and Y-1 mutant of Chlamydomonas reinhardtii. J Cell Biol 106:609-616

Marder JB, Goloubinoff P, Edelman M (1984) Molecular architecture of the rapidly metabolized 32-kilodalton protein of photosystem II. Indications for $\mathrm{COOH}$-terminal processing of a chloroplast membrane polypeptide. J Biol Chem 259:3900-3908

Marin-Navarro J, Manuell AL, Wu J, Mayfield SP (2007) Chloroplast translation regulation. Photosynth Res 94:359-374

Martin W, Russell MJ (2003) On the origins of cells: a hypothesis for the evolutionary transitions from abiotic geochemistry to chemoautotrophic prokaryotes, and from prokaryotes to nucleated cells. Philos Trans R Soc Lond B Biol Sci 358:59-83 (discussion 83-55)

Martin W, Rujan T, Richly E, Hansen A, Cornelsen S, Lins T, Leister D, Stoebe B, Hasegawa M, Penny D (2002) Evolutionary analysis of Arabidopsis, cyanobacterial, and chloroplast genomes reveals plastid phylogeny and thousands of cyanobacterial genes in the nucleus. Proc Natl Acad Sci USA 99:12246-12251

Mathy N, Benard L, Pellegrini O, Daou R, Wen T, Condon C (2007) $5^{\prime}$-to-3' exoribonuclease activity in bacteria: role of RNase $\mathrm{J} 1$ in rRNA maturation and 5' stability of mRNA. Cell 129:681-692

Mattoo AK, Pick U, Hoffman-Falk H, Edelman M (1981) The rapidly metabolized 32,000-dalton polypeptide of the chloroplast is the "proteinaceous shield" regulating photosystem II electron transport and mediating diuron herbicide sensitivity. Proc Natl Acad Sci USA 78:1572-1576

Maul JE, Lilly JW, Cui L, dePamphilis CW, Miller W, Harris EH, Stern DB (2002) The Chlamydomonas reinhardtii plastid chromosome: Islands of genes in a sea of repeats. Plant Cell 14:2659-2679

Mayfield SP, Cohen A, Danon A, Yohn CB (1994) Translation of the psbA mRNA of Chlamydomonas reinhardtii requires a structured RNA element contained within the $5^{\prime}$ untranslated region. J Cell Biol 127:1537-1545

Meierhoff K, Felder S, Nakamura T, Bechtold N, Schuster G (2003) HCF152, an Arabidopsis RNA binding pentatricopeptide repeat protein involved in the processing of chloroplast $p s b B$ - $p s b T$ psbH-petB-petD RNAs. Plant Cell 15:1480-1495

Meurer J, Plücken H, Kowallik KV, Westhoff P (1998) A nuclearencoded protein of prokaryotic origin is essential for the stability of photosystem II in Arabidopsis thaliana. EMBO J 17:5286-5297
Meurer J, Lezhneva L, Amann K, Gödel M, Bezhani S, Sherameti I, Oelmüller R (2002) A peptide chain release factor 2 affects the stability of UGA-containing transcripts in Arabidopsis chloroplasts. Plant Cell 14:3255-3269

Michel F, Umesono K, Ozeki H (1989) Comparative and functional anatomy of group II catalytic introns-a review. Gene 82:5-30

Minai L, Wostrikoff K, Wollman FA, Choquet Y (2006) Chloroplast biogenesis of photosystem II cores involves a series of assemblycontrolled steps that regulate translation. Plant Cell 18:159-175

Moore M, Harrison MS, Peterson EC, Henry R (2000) Chloroplast Oxa1p homolog Albino3 is required for post-translational integration of the light harvesting chlorophyll-binding protein into thylakoid membranes. J Biol Chem 275:1529-1532

Mühlbauer SK, Eichacker LA (1998) Light-dependent formation of the photosynthetic proton gradient regulates translation elongation in chloroplasts. J Biol Chem 273:20935-20940

Mullet JE (1993) Dynamic regulation of chloroplast transcription. Plant Physiol 103:309-313

Mullet JE, Klein PG, Klein RR (1990) Chlorophyll regulates accumulation of the plastid-encoded chlorophyll apoproteins CP43 and D1 by increasing apoprotein stability. Proc Natl Acad Sci USA 87:4038-4042

Mulo P, Sirpiö S, Suorsa M, Aro EM (2008) Auxiliary proteins involved in the assembly and sustenance of photosystem II. Photosynth Res 98:489-501

Munekage Y, Shikanai T (2005) Cyclic electron transport through photosystem I. Plant Biotechnol 22:361-369

Munekage Y, Hashimoto C, Miyake K, Tomizawa T, Endo M, Tasaka T, Shikanai T (2004) Cyclic electron flow around photosystem I is essential for photosynthesis. Nature 429:579-582

Nakamura Y, Ito K (1998) How protein reads the stop codon and terminates translation. Genes Cells 3:265-278

Neckermann K, Zeltz P, Igloi GL, Kössel H, Maier RM (1994) The role of RNA editing in conservation of start codons in chloroplast genomes. Gene 146:177-182

Nelson N, Ben-Shem A (2004) The complex architecture of oxygenic photosynthesis. Nat Rev Mol Cell Biol 5:971-982

Neuhaus HE, Emes MJ (2000) Nonphotosynthetic metabolism in plastids. Annu Rev Plant Physiol Plant Mol Biol 51:111-140

Nickelsen J, Fleischmann M, Boudreau E, Rahire M, Rochaix JD (1999) Identification of cis-acting RNA leader elements required for chloroplast $p s b D$ gene expression in Chlamydomonas. Plant Cell 11:957-970

Nixon PJ, Trost JT, Diner BA (1992) Role of the carboxy terminus of polypeptide D1 in the assembly of a functional water-oxidizing manganese cluster in photosystem II of the cyanobacterium Synechocystis sp. PCC 6803: assembly requires a free carboxyl group at C-terminal position 344. Biochemistry 31:10859-10871

Ohad I, Adir N, Koike H, Kyle DJ, Inoue Y (1990) Mechanism of photoinhibition in vivo. A reversible light-induced conformational change of reaction center II is related to an irreversible modification of the D1 protein. J Biol Chem 265:1972-1979

Okuda K, Nakamura T, Sugita M, Shimizu T, Shikanai T (2006) A pentatricopeptide repeat protein is a site recognition factor in chloroplast RNA editing. J Biol Chem 281:37661-37667

Okuda K, Myouga F, Motohashi R, Shinozaki K, Shikanai T (2007) Conserved domain structure of pentatricopeptide repeat proteins involved in chloroplast RNA editing. Proc Natl Acad Sci USA 104:8178-8183

Okuda K, Chateigner-Boutin AL, Nakamura T, Delannoy E, Sugita M, Myouga F, Motohashi R, Shinozaki K, Small I, Shikanai T (2009) Pentatricopeptide repeat proteins with the DYW motif have distinct molecular functions in RNA editing and RNA cleavage in Arabidopsis chloroplasts. Plant Cell 21:146-156

Onda Y, Yagi Y, Saito Y, Takenaka N, Toyoshima Y (2008) Light induction of Arabidopsis SIG1 and SIG5 transcripts in mature 
leaves: differential roles of cryptochrome 1 and cryptochrome 2 and dual function of SIG5 in the recognition of plastid promoters. Plant J 55:968-978

Ossenbühl F, Nickelsen J (2000) Cis- and trans-acting determinants for translation of $p s b D$ mRNA in Chlamydomonas reinhardtii. Mol Cell Biol 20:8134-8142

Ozawa S, Onishi T, Takahashi Y (2010) Identification of an assembly intermediate subcomplec of photosystem I in the green alga Chlamydomonas reinhardtii. J Biol Chem 285:20072-20079

Page ML, Hamel PP, Gabilly ST, Zegzouti H, Perea JV, Alonso JM, Ecker JR, Theg SM, Christensen SK, Merchant S (2004) A homo$\log$ of prokaryotic thiol disulfide transporter CcdA is required for the assembly of the cytochrome $b_{6} f$ complex in Arabidopsis chloroplasts. J Biol Chem 279:32474-32482

Pasch JC, Nickelsen J, Schünemann D (2005) The yeast split-ubiquitin system to study chloroplast membrane protein interactions. Appl Microbiol Biotechnol 69:440-447

Peng L, Ma J, Chi W, Guo J, Zhu S, Lu Q, Lu C, Zhang L (2006) LOW PSII ACCUMULATION1 is involved in efficient assembly of photosystem II in Arabidopsis thaliana. Plant Cell 18:955-969

Pfalz J, Liere K, Kandlbinder A, Dietz KJ, Oelmüller R (2006) pTAC2, -6 and -12 are components of the transcriptionally active chromosome that are required for plastid gene expression. Plant Cell 18:176-197

Pfalz J, Bayraktar OA, Prikryl J, Barkan A (2009) Site-specific binding of a PPR protein defines and stabilizes $5^{\prime}$ and $3^{\prime}$ mRNA termini in chloroplasts. EMBO J 28:2042-2052

Pfannschmidt T (2010) Plastidial retrograde signalling — a true "plastid factor" or just metabolite signatures? Trends Plant Sci 15:427-435

Plader W, Sugiura M (2003) The Shine-Dalgarno-like sequence is a negative regulatory element for translation of tobacco chloroplast rps2 mRNA: an additional mechanism for translational control in chloroplasts. Plant J 34:377-382

Plücken H, Müller B, Grohmann D, Westhoff P, Eichacker LA (2002) The HCF136 protein is essential for assembly of the photosystem II reaction center in Arabidopsis thaliana. FEBS Lett 532:85-90

Pogson BJ, Woo NS, Förster B, Small ID (2008) Plastid signalling to the nucleus and beyond. Trends Plant Sci 13:602-609

Prikryl J, Rojas M, Schuster G, Barkan A (2011) Mechanism of RNA stabilization and translational activation by a pentatricopeptide repeat protein. Proc Natl Acad Sci USA 108:415-420

Pyle AM, Lambowitz AM (2006) Group II introns: ribozymes that splice RNA and invade DNA. In: Gesteland RF, Cech TR, Atkins JF (eds) The RNA world, 3rd edn. Cold Spring Harbor Lab, Cold Spring Harbor, pp 469-505

Rattanachaikunsopon P, Rosch C, Kuchka MR (1999) Cloning and characterization of the nuclear AC115 gene of Chlamydomonas reinhardtii. Plant Mol Biol 39:1-10

Raynaud C, Loiselay C, Wostrikoff K, Kuras R, Girard-Bascou J, Wollman FA, Choquet Y (2007) Evidence for regulatory function of nucleus-encoded factors on mRNA stabilization and translation in the chloroplast. Proc Natl Acad Sci USA 104:9093-9098

Richly E, Leister D (2004) An improved prediction of chloroplast proteins reveals diversities and commonalities in the chloroplast proteomes of Arabidopsis and rice. Gene 329:11-16

Robertson DE, Farid RS, Moser CC, Urbauer JL, Mulholland SE, Pidikiti R, Lear JD, Wand AJ, DeGrado WF, Dutton PL (1994) Design and synthesis of multi-haem proteins. Nature 368:425432

Rohl T, van Wijk KJ (2001) In vitro reconstitution of insertion and processing of cytochrome $f$ in a homologous chloroplast translation system. J Biol Chem 276:35465-35472

Rokka A, Suorsa M, Saleem A, Battchikova N, Aro EM (2005) Synthesis and assembly of thylakoid protein complexes: multiple assembly steps of photosystem II. Biochem J 388:159-168
Roose JL, Pakrasi HB (2004) Evidence that D1 processing is required for manganese binding and extrinsic protein assembly into photosystem II. J Biol Chem 279:45417-45422

Rurek M (2008) Proteins involved in maturation pathways of plant mitochondrial and plastid $c$-type cytochromes. Acta Biochim Pol 55:417-433

Ruwe H, Schmitz-Linneweber C (2012) Short non-coding RNA fragments accumulating in chloroplasts: footprints of RNA binding proteins? Nucl Acid Res 40:3106-3116

Saint-Marcoux D, Wollman FA, de Vitry C (2009) Biogenesis of cytochrome $b_{6}$ in photosynthetic membranes. J Cell Biol 185:11951207

Sakamoto W, Chen X, Kindle KL, Stern DB (1994) Function of the Chlamydomonas reinhardtii petD $5^{\prime}$ untranslated region in regulating the accumulation of subunit IV of the cytochrome $b_{6} f$ complex. Plant J 6:503-512

Sanders C, Turkarslan S, Lee DW, Daldal F (2010) Cytochrome $c$ biogenesis: the Ccm system. Trends Microbiol 18:266-274

Sane AP, Stein B, Westhoff P (2005) The nuclear gene HCF107 encodes a membrane-associated R-TPR (RNA-tetratricopeptide repeat)-containing protein involved in expression of the plastidal psbH gene in Arabidopsis. Plant J 42:720-730

Sasaki T, Yukawa Y, Wakasugi T, Yamada K, Sugiura M (2006) A simple in vitro RNA editing assay for chloroplast transcripts using fluorescent dideoxynucleotides: distinct types of sequence elements required for editing of $n d h$ transcripts. Plant J 47:802810

Sato S, Nakamura Y, Kaneko T, Asamizu E, Tabata S (1999) Complete structure of the chloroplast genome of Arabidopsis thaliana. DNA Res 6:283-290

Schein A, Sheffy-Levin S, Glaser F, Schuster G (2008) The RNase E/G-type endoribonuclease of higher plants is located in the chloroplast and cleaves RNA similarly to the E. coli enzyme. RNA 14:1057-1068

Schmitz-Linneweber C, Barkan A (2007) RNA splicing and RNA editing in chloroplasts. In: Bock R (ed) Cell and molecular biology of plastids. Springer, Heidelberg, pp 213-248

Schmitz-Linneweber C, Small I (2008) Pentatricopeptide repeat proteins: a socket set for organelle gene expression. Trends Plant Sci 13:663-670

Schmitz-Linneweber C, Williams-Carrier R, Barkan A (2005) RNA immunoprecipitation and microarray analysis show a chloroplast pentatricopeptide repeat protein to be associated with the $5^{\prime}$ region of mRNAs whose translation it activates. Plant Cell 17:2791-2804

Schöttler MA, Albus CA, Bock R (2011) Photosystem I: its biogenesis and function in higher plants. J Plant Physiol 168:1452-1461

Schröter Y, Steiner S, Matthäi K, Pfannschmidt T (2010) Analysis of oligomeric protein complexes in the chloroplast sub-proteome of nucleic acid-binding proteins from mustard reveals potential redox regulators of plastid gene expression. Proteomics 10:21912204

Schünemann D (2004) Structure and function of the chloroplast signal recognition particle. Curr Genet 44:295-304

Schwarz C, Elles I, Kortmann J, Piotrowski M, Nickelsen J (2007) Synthesis of the D2 protein of photosystem II in Chlamydomonas is controlled by a high molecular mass complex containing the RNA stabilization factor Nac2 and the translational activator RBP40. Plant Cell 19:3627-3639

Schwarz C, Bohne AV, Wang F, Cejudo FJ, Nickelsen J (2012) An intermolecular disulfide-based light switch for chloroplast $p s b D$ gene expression in Chlamydomonas reinhardtii. Plant $\mathrm{J}$ (in press)

Schwenkert S, Netz DJ, Frazzon J, Pierik AJ, Bill E, Gross J, Lill R, Meurer J (2010) Chloroplast HCF101 is a scaffold protein for [4Fe-4S] cluster assembly. Biochem J 425:207-214 
Scolnick E, Tompkins R, Caskey T, Nirenberg M (1968) Release factors differing in specificity for terminator codons. Proc Natl Acad Sci USA 61:768-774

Shen G, Antonkine ML, van der Est A, Vassiliev IR, Brettel K, Bittl R, Zech SG, Zhao J, Stehlik D, Bryant DA, Golbeck JH (2002) Assembly of photosystem I. Rubredoxin is required for the in vivo assembly of F(X) in Synechococcus sp. PCC 7002 as shown by optical and EPR spectroscopy. J Biol Chem 277:20355-20366

Shiina T, Tsunoyama Y, Nakahira Y, Khan MS (2005) Plastid RNA polymerases, promoters, and transcription regulators in higher plants. Int Rev Cytol 244:1-68

Shikanai T (2007) Cyclic electron transport around photosystem I: genetic approaches. Annu Rev Plant Biol 58:199-217

Shirano Y, Shimada H, Kanamaru K, Fujiwara M, Tanaka K, Takahashi H, Unno K, Sato S, Tabata S, Hayashi H, Miyake C, Yokota A, Shibata D (2000) Chloroplast development in Arabidopsis thaliana requires the nuclear-encoded transcription factor sigma B. FEBS Lett 485:178-182

Sirpiö S, Allahverdiyeva Y, Suorsa M, Paakkarinen V, Vainonen J, Battchikova N, Aro EM (2007) TLP18.3, a novel thylakoid lumen protein regulating photosystem II repair cycle. Biochem J 406:415-425

Somanchi A, Barnes D, Mayfield SP (2005) A nuclear gene of Chlamydomonas reinhardtii, Tbal, encodes a putative oxidoreductase required for translation of the chloroplast $p s b A$ mRNA. Plant $\mathrm{J}$ 42:341-352

Steiner S, Schröter Y, Pfalz Y, Pfannschmidt T (2011) Identification of essential subunits in the plastid-encoded RNA polymerase complex reveals building blocks for proper plastid development. Plant Physiol 173:1043-1055

Stern DB, Goldschmidt-Clermont M, Hanson MR (2010) Chloroplast RNA metabolism. Annu Rev Plant Biol 61:125-155

Stöckel J, Bennewitz S, Hein P, Oelmüller R (2006) The evolutionarily conserved tetratricopeptiderepeat protein pale yellow green 7 is required for photosystem I accumulation in Arabidopsis and copurifies with the complex. Plant Physiol 141:870-878

Stroebel D, Choquet Y, Popot JL, Picot D (2003) An atypical haem in the cytochrome $b_{6} f$ complex. Nature 426:413-418

Sturm NR, Kuras R, Buschlen S, Sakamoto W, Kindle KL, Stern DB, Wollman FA (1994) The petD gene is transcribed by functionally redundant promoters in Chlamydomonas reinhardtii chloroplasts. Mol Cell Biol 14:6171-6179

Subramanian AR (1993) Molecular genetics of chloroplast ribosomal proteins. Trends Biochem Sci 18:177-181

Sugita M, Miyata Y, Maruyama K, Sugiura C, Arikawa T, Higuchi M (2006) Extensive RNA editing in transcripts from the $p s b B$ operon and rpoA gene of plastids from the enigmatic moss Takakia lepidozioides. Biosci Biotechnol Biochem 70:2268-2274

Sugiura M (1992) The chloroplast genome. Plant Mol Biol 19:149-168

Sugiura M, Hirose T, Sugita M (1998) Evolution and mechanism of translation in chloroplasts. Annu Rev Genet 32:437-459

Suzuki JY, Ytterberg AJ, Beardslee T, Allison LA, van Wijk KJ, Maliga P (2004) Affinity purification of the tobacco plastid RNA polymerase and in vitro reconstitution of the holoenzyme. Plant $\mathrm{J}$ 40:164-172

Swiatecka-Hagenbruch M, Liere K, Börner T (2007) High diversity of plastidial promoters in Arabidopsis thaliana. Mol Genet Genomics 277:725-734

Swiatecka-Hagenbruch M, Emanuel C, Hedtke B, Liere K, Börner T (2008) Impaired function of the phage-type RNA polymerase RpoTp in transcription of chloroplast genes is compensated by a second phage-type RNA polymerase. Nucleic Acids Res 36:785792

Takahashi M, Shiraishi T, Asada K (1988) COOH-terminal residues of $\mathrm{D} 1$ and the $44 \mathrm{kDa} \mathrm{CPa}-2$ at spinach photosystem II core complex. FEBS Lett 240:6-8
Tiller N, Weingartner M, Thiele W, Maximova E, Schöttler MA, Bock R (2012) The plastid-specific ribosomal proteins of Arabidopsis thaliana can be divided into non-essential proteins and genuine ribosomal proteins. Plant J 69:302-316

Tillich M, Funk HT, Schmitz-Linneweber C, Poltnigg P, Sabater B, Martin M, Maier RM (2005) Editing of plastid RNA in Arabidopsis thaliana ecotypes. Plant J 43:708-715

Timmis JN, Ayliffe MA, Huang CY, Martin W (2004) Endosymbiotic gene transfer: Organelle genomes forge eukaryotic chromosomes. Nat Rev Genet 5:123-135

Turmel M, Gutell RR, Mercier JP, Otis C, Lemieux C (1993) Analysis of the chloroplast large subunit ribosomal RNA gene from 17 Chlamydomonas taxa. Three internal transcribed spacers and 12 group I intron insertion sites. J Mol Biol 232:446-467

Wank H, SanFilippo J, Singh RN, Matsuura M, Lambowitz AM (1999) A reverse transcriptase/maturase promotes splicing by binding at its own coding segment in a group II intron RNA. Mol Cell $4: 239-250$

Wei L, Guo J, Ouyang M, Sun X, Ma J, Chi W, Lu C, Zhang L (2010) LPA19, a Psb27 homolog in Arabidopsis thaliana, facilitates D1 protein precursor processing during PSII biogenesis. J Biol Chem 285:21391-21398

Wolf PG, Rowe CA, Hasebe M (2004) High levels of RNA editing in a vascular plant chloroplast genome: analysis of transcripts from the fern Adiantum capillus-veneris. Gene 339:89-97

Wollman FA, Minai L, Nechushtai R (1999) The biogenesis and assembly of photosynthetic proteins in thylakoid membranes 1 . Biochim Biophys Acta 1411:21-85

Woodson JD, Chory J (2008) Coordination of gene expression between organellar and nuclear genomes. Nat Rev Genet 9:383395

Wostrikoff K, Girard-Bascou J, Wollman FA, Choquet Y (2004) Biogenesis of PSI involves a cascade of translational autoregulation in the chloroplast of Chlamydomonas. EMBO J 23:26962705

Xie Z, Merchant S (1996) The plastid-encoded ccsA gene is required for heme attachment to chloroplast $c$-type cytochromes. J Biol Chem 271:4632-4639

Xie Z, Merchant S (1998) A novel pathway for cytochromes $c$ biogenesis in chloroplasts. Biochim Biophys Acta 1365:309318

Yamaguchi K, Prieto S, Beligni MV, Haynes PA, McDonald WH, Yates JR 3rd, Mayfield SP (2002) Proteomic characterization of the small subunit of Chlamydomonas reinhardtii chloroplast ribosome: identification of a novel S1 domain-containing protein and unusually large orthologs of bacterial S2, S3, and S5. Plant Cell 14:2957-2974

Yamaguchi K, Beligni MV, Prieto S, Haynes PA, McDonald WH, Yates JR 3rd, Mayfield SP (2003) Proteomic characterization of the Chlamydomonas reinhardtii chloroplast ribosome. Identification of proteins unique to the 70 S ribosome. J Biol Chem 278: 33774-33785

Yehudai-Resheff S, Hirsh M, Schuster G (2001) Polynucleotide phosphorylase functions as both an exonuclease and a poly(A) polymerase in spinach chloroplasts. Mol Cell Biol 21: 54085416

Yohn CB, Cohen A, Danon A, Mayfield SP (1998) A poly(A) binding protein functions in the chloroplast as a message-specific translation factor. Proc Natl Acad Sci USA 95:2238-2243

Yusupova GZ, Yusupov MM, Cate JH, Noller HF (2001) The path of messenger RNA through the ribosome. Cell 106:233-241

Zerges W (2000) Translation in chloroplasts. Biochimie 82:583-601

Zerges W, Girard-Bascou J, Rochaix JD (1997) Translation of the chloroplast $p s b C$ mRNA is controlled by interactions between its $5^{\prime}$ leader and the nuclear loci TBC1 and TBC3 in Chlamydomonas reinhardtii. Mol Cell Biol 17:3440-3448 
Zerges W, Auchincloss AH, Rochaix JD (2003) Multiple translational control sequences in the $5^{\prime}$ leader of the chloroplast $p s b C$ mRNA interact with nuclear gene products in Chlamydomonas reinhardtii. Genetics 163:895-904

Zhang L, Paakkarinen V, van Wijk KJ, Aro EM (2000) Biogenesis of the chloroplast-encoded D1 protein: regulation of translation elongation, insertion, and assembly into photosystem II. Plant Cell 12:1769-1782

Zhang L, Paakkarinen V, Suorsa M, Aro EM (2001) A SecY homologue is involved in chloroplast-encoded D1 protein biogenesis. J Biol Chem 276:37809-37814

Zhelyazkova P, Hammani K, Rojas M, Voelker R, Vargas-Suárez M, Börner T, Barkan A (2012) Protein-mediated protection as the predominant mechanism for defining processed mRNA termini in land plant chloroplasts. Nucl Acid Res 40:3092-3105

Zhou W, Cheng Y, Yap A, Chateigner-Boutin AL, Delannoy E, Hammani K, Small I, Huang J (2009) The Arabidopsis gene YSI encoding a DYW protein is required for editing of $r p o B$ transcripts and the rapid development of chloroplasts during early growth. Plant J 58:82-96

Zito F, Kuras R, Choquet Y, Kössel H, Wollman FA (1997) Mutations of cytochrome $b_{6}$ in Chlamydomonas reinhardtii disclose the functional significance for a proline to leucine conversion by pet $B$ editing in maize and tobacco. Plant Mol Biol 33:79-86

Zoschke R, Liere K, Börner T (2007) From seedling to mature plant: Arabidopsis plastidial genome copy number, RNA accumulation and transcription are differentially regulated during leaf development. Plant J 50:710-722

Zoschke R, Nakamura M, Liere K, Sugiura M, Börner T, SchmitzLinneweber C (2010) An organellar maturase associates with multiple group II introns. Proc Natl Acad Sci USA 107:32453250 